\title{
Evaluation of bioactivities of methanol and petroleum ether extracts of Cassia renigera seed
}

\author{
Md. Monir Hossain ${ }^{1,2^{*}}$ (D) Milon Mondal ${ }^{2}$, Rayhan Uddin Morad², Nizam Uddin², Abhijit Das ${ }^{3}$, Md. Sazzad Hossain²,
} Mohammad Mostafa Kamal ${ }^{2,4}$, Md. Fokhrul Islam², Tania Binte Wahed ${ }^{2}$ and Mohammed Motaher Hossain Chowdhury ${ }^{2}$

\begin{abstract}
Background: To investigate in vitro antioxidant, brine shrimp lethality bioassay, antimicrobial, anthelmintic activities and in vivo peripheral analgesic activity of methanol and petroleum ether extracts of Cassia renigera seed.

Methods: Phytochemical screening of the crude extracts was carried out. Antioxidant activity was determined using seven different methods. Brine shrimp lethality bioassay and anthelmintic activities were done using nauplii of Artemia salina and adult earthworm (Pheretima posthuma), respectively. The antimicrobial potential was investigated against three Gram-positive and three Gram-negative bacteria. Acetic acid induced writhing test was performed to evaluate peripheral analgesic activity.

Results: Both methanol and petroleum ether extracts showed the presence of flavonoids, saponins, and tannins. While alkaloids, glycosides, and steroids were only found in the methanolic extract. Methanolic extract showed more potent 1,1- diphenyl-2-picrylhydrazyl (DPPH), nitric oxide scavenging capacity, cupric reducing and reducing power capacity than petroleum ether extract. While petroleum ether extract showed better results in total phenol and total antioxidant activities. In brine shrimp lethality bioassay methanolic and petroleum ether extracts showed the $L C_{50}$ value of 74.44 and $121.49 \mu \mathrm{g} / \mathrm{mL}$, respectively. In overall antimicrobial study methanolic extract showed better activity than petroleum ether extract. Methanolic extract of $50 \mathrm{mg} / \mathrm{mL}$ showed maximum anthelmintic activity comparable to the standard (Piperazine Citrate, $10 \mathrm{mg} / \mathrm{mL}$ ). Both $500 \mathrm{mg} / \mathrm{kg}$ and $1000 \mathrm{mg} / \mathrm{kg}$ body weight dose of the methanolic extract exhibited significant $39.64 \%$ and $58.73 \%$ writhing inhibition ( $<0.05$ ) in test animals, consecutively.
\end{abstract}

Conclusions: In a nutshell, the results suggested that the seed can be used as a potential source for the aforesaid bioactivities.

Keywords: Cassia renigera, DPPH, Brine shrimp lethality, Antimicrobial activity, Anthelmintic activity, Analgesic activity

\section{Background}

Plants are more important in human life and commonly used in treating or preventing specific diseases and are considered to play a salubrious role in health care. Various experimental studies indicated that peptide, unsaturated long chain fatty acids, alkaloids, essential oils, phenols, flavonoids, tannin, and water or ethanol soluble compounds of medicinal plants are potentially significant

\footnotetext{
* Correspondence: monirjupharmacy@gmail.com

'Department of Pharmacy, Mawlana Bhashani Science and Technology

University, Santosh, Tangail 1902, Bangladesh

2Department of Pharmacy, Jahangirnagar University, Savar, Dhaka 1342,

Bangladesh

Full list of author information is available at the end of the article
}

against different diseases [1]. Free radicals are the main cause of oxidative stress and the source of the pathogenesis of various diseases like cancer, diabetes, cardiovascular diseases, aging and metabolic syndrome [2]. These radicals can be scavenged by natural and synthetic antioxidant agents. Multiple drug resistance has become very common and to combat the challenge there have been rising interests to find antimicrobial compounds from medicinal plant extracts [3] Parasitic infection (Helminthiasis) is a further serious healthcare problem in the tropical regions including the Asian countries which affects more than two billions of people worldwide [4]. The finding of different natural anthelmintics is also very important. Inflammation 
is a reaction of living tissues towards injury and leads to the restoration of a normal tissue structure and function which comprises systemic and local responses. Prolonged inflammation causes the pathogenesis of many inflammatory diseases such as atherosclerosis, obesity, cardiovascular disease, rheumatoid arthritis, and cancer [5]. So investigation of medicinal properties of plants devoted an increasing interest last couple of years because of their potent pharmacological activities, convenience to users, economic variability and low toxicity.

Cassia spp. of Caesalpiniaceae family has drawn attention due to their significant therapeutic value in traditional medicine for their antioxidant, antimicrobial and antidiabetic activities [6]. Among Cassia spp. Cassia renigera (C. renigera) is an evergreen tree is locally conversant as Minjiri and English name is Burmese Pink Shower. It is indigenous in Myanmar but also found in India and Bangladesh. Generally, the seed is not eaten by a human but the seed of this plant is used in constipation [7]. Previously Hossain et al in 2014 investigated antioxidant, brine shrimp lethality bioassay and antimicrobial activities of fruits of C. renigera [7]. To the best of our consciousness, no attempts were taken before to evaluate the bioactivities of the seed part of this plant. So in this present study, we have viewed antioxidant, brine shrimp lethality bioassay, antimicrobial, antihelminthic and analgesic activities of methanol and petroleum ether extracts of seed part of $C$. renigera.

\section{Materials and methods}

\section{Chemicals and reagents}

Folin-Ciocalteu reagent, Methanol, Ethanol, Sodium Phosphate (Na3PO4) and Ammonium molybdate were purchased from Merck, Germany. Sodium carbonate, Potassium Acetate and Concentrated H2SO4 (98\%), Cupric Chloride, Neocaproin, Ammonium acetate Buffer ( $\mathrm{pH}$ 7.0), were purchased from Merck (India) Limited. Gallic acid, Quercetin and 1, 1-diphenyl-2-picrylhydrazyl $(\mathrm{DPPH})$ were purchased from Sigma Chemicals, USA. Aluminium Chloride and Ascorbic acid were purchased from SD Fine Chem. Ltd., Biosar, India. Sodium Nitroprusside was purchased from Ranbaxy lab, Mohali, India. Griess reagent was purchased from Rouch-light, Suffolk, England. Potassium Ferricyanide was purchased from May and Becker, Dagenham, UK. Trichloro Acetic acid and Ferric Chloride were purchased from Fine Chemical, India. Diclofenac sodium was obtained from Beximco Pharmaceuticals Ltd., Bangladesh. All reagents and chemicals used were of analytical grade.

\section{Plant materials}

The seeds of C. renigera were collected in OctoberNovember 2016 from the Botanical garden of Jahangirnagar University, Savar, Dhaka, Bangladesh. The plants were identified by the taxonomist of the National Herbarium of Bangladesh (Acc. No. 38731) where the voucher specimen has been deposited for future investigation.

\section{Extract preparation}

The seeds of $C$. renigera were collected, sundried and then dried in a hot air oven (Size 1, Gallenkamp) at reduced temperature (not more than $50{ }^{\circ} \mathrm{C}$ ) to make suitable for grinding purpose. The dried seeds were ground to a coarse powder with a mechanical grinder (Grinding Mill). The weight of the powdered seeds was $1100 \mathrm{~g}$. One thousand gram powders were used for extraction. The powdered seeds were extracted by Soxhlet apparatus at an elevated temperature $\left(65^{\circ} \mathrm{C}\right)$ using petroleum ether and methanol consecutively (1000 mL of each solvent). After each extraction, the plant material was dried and used again for the next extraction. The filtrates obtained were dried at a temperature of $40 \pm 2{ }^{\circ} \mathrm{C}$ to haven gummy concentrate of the crude extracts. In the suitable container, the extracts were sored with proper leveling and maintaining other proper conditions. The yield obtained from seed using petroleum ether was $18.4 \mathrm{~g}$ and methanol was $37.5 \mathrm{~g}$.

\section{Phytochemical screening}

Phytochemical screening of the crude extracts was carried out employing standard procedures [8], to reveal the presence of different phytochemical constituents such as alkaloids, carbohydrates, flavonoids, glycosides, tannins, steroids, and saponins.

\section{Antioxidant activity evaluation Determination of total phenol content}

The content of total phenolic compounds in seed methanol and petroleum ether extracts was determined as described by Velioglu et al [9]. After addition of Folin-Ciocalteu and $7.5 \%$ Sodium carbonate solution $(4 \mathrm{~mL})$ into different concentrations of seed extract/ standard, mixed well. The absorbance of the solution was measured at $765 \mathrm{~nm}$ using a spectrophotometer (Shimadzu UV PC-1600) against blank. The total content of phenolic compounds of the seed extracts was expressed in $\mathrm{mg} / \mathrm{g}$ gallic acid equivalent (GAE).

\section{Determination of total flavonoid content}

Total flavonoid was determined using the aluminum chloride colorimetric method described by Wang and Jiao [10]. Three $\mathrm{mL}$ of methanol was added to the test tube containing a different concentration of seed extract/ standard. Then $200 \mu \mathrm{L}$ of $10 \%$ aluminum chloride solution was added into the same test tube, followed by the addition of $200 \mu \mathrm{L}$ of $1 \mathrm{M}$ potassium acetate solution into the test tube. Finally, $5.6 \mathrm{~mL}$ of distilled water was mixed and incubated for $30 \mathrm{~min}$ at room temperature. The absorbance of the solution was measured at $415 \mathrm{~nm}$ 
using a UV spectrophotometer against blank. In seed extracts, total flavonoid contents were expressed in $\mathrm{mg} / \mathrm{g}$ quercetin equivalent $(\mathrm{QE})$.

\section{Determination of total antioxidant capacity}

Total antioxidant capacity was determined using the phosphomolybdenum method described by Prieto et al [11]. Three $\mathrm{mL}$ of reagent solution was added into test tubes of different concentration of seed extract/standard. It was incubated for $90 \mathrm{~min}$ at $95{ }^{\circ} \mathrm{C}$. Then after cooling at room temperature the absorbance of the solutions was measured using a spectrophotometer against blank at $695 \mathrm{~nm}$. The antioxidant activity was expressed as $\mathrm{mg} / \mathrm{g}$ ascorbic acid equivalent (AAE).

\section{DPPH free radical scavenging assay}

DPPH free radical scavenging assay was done according to the method described by Braca et al [12]. In different concentration solutions of seed extract/standard, $2 \mathrm{~mL}$ of $0.004 \%$ DPPH solution in the solvent was added to each test tube to make the final volume $3 \mathrm{~mL}$. After incubating for $30 \mathrm{~min}$ at room temperature in a dark place, absorbance was measured at $517 \mathrm{~nm}$ using a spectrophotometer against blank. The percentage (\%) inhibition activity was calculated from the following equation. ((A0-A1)/A0) $\times$ 100 ; where $\mathrm{A} 0$ is the absorbance of the control and $\mathrm{A} 1$ is the absorbance of the extract or standard. IC50 values were calculated using regression analysis.

\section{Nitric oxide (NO) scavenging capacity assay}

Nitric oxide scavenging capacity was determined according to the method described by Govindarajan et al [13]. In different test tubes, $4.0 \mathrm{~mL}$ of each seed extracts or standard of different concentration solutions were taken and $1.0 \mathrm{~mL}$ of Sodium nitroprusside, $(5 \mathrm{mM})$ solution was added into the test tubes. The test tubes were incubated for $2 \mathrm{~h}$ at $30{ }^{\circ} \mathrm{C}$ to complete the reaction. Then $2.0 \mathrm{~mL}$ solution was withdrawn from the mixture and mix with $1.2 \mathrm{~mL}$ of Griess reagent and the absorbances of the solutions were measured at $550 \mathrm{~nm}$ using a spectrophotometer against blank. The percentage (\%) inhibition activity was calculated from the following equation. $((\mathrm{A} 0-\mathrm{A} 1) / \mathrm{A} 0) \times 100$; where $\mathrm{A} 0$ is the absorbance of the control and A1 is the absorbance of the extract or standard. IC50 was calculated by a linear regression method.

\section{Cupric reducing antioxidant capacity}

The cupric reducing antioxidant capacity was done according to the CUPRAC method described by Resat et al [14]. One $\mathrm{mL}$ of $0.01 \mathrm{M} \mathrm{CuCl} 2.2 \mathrm{H} 2 \mathrm{O}$ solution, $1.0 \mathrm{~mL}$ of ammonium acetate buffer, $\mathrm{pH} 7.0,1.0$ of $0.0075 \mathrm{~mL}$ of neocaproin solution and $600 \mu \mathrm{L}$ of distilled water were added into test tubes containing seed extracts/standards of different concentrations and the final volume of the mixture was adjusted to $4.1 \mathrm{~mL}$. After incubating for $1 \mathrm{~h}$ at room temperature the absorbance of the solutions was measured at $450 \mathrm{~nm}$ using a spectrophotometer against blank.

\section{Reducing power capacity assessment}

In this assay, the reducing power capacity was performed according to the way described by Oyaizu [15]. In different test tubes, $2.0 \mathrm{~mL}$ of each seed extracts or standard of different concentration solutions were taken and $2.5 \mathrm{~mL}$ of $1 \%$ Potassium ferricyanide $(\mathrm{K} 3 \mathrm{Fe}(\mathrm{CN}) 6)$ solution was added into each of test tubes. The test tubes were incubated for $10 \mathrm{~min}$ at $50{ }^{\circ} \mathrm{C}$ to complete the reaction and $2.5 \mathrm{~mL}$ of Trichloroacetic acid, $10 \%$ solution was added to each of the test tubes. The total mixtures were centrifuged at $3000 \mathrm{rpm}$ for $10 \mathrm{~min} .2 .5 \mathrm{~mL}$ supernatant solution was withdrawn from each of the mixtures and mixed with $2.5 \mathrm{~mL}$ of distilled water. $0.5 \mathrm{~mL}$ of $0.1 \%$ Ferric chloride $(\mathrm{FeCl} 3)$ solution was added to each of the test tubes. The absorbance of the solutions was measured at $700 \mathrm{~nm}$ using a spectrophotometer against distilled water. The absorbance of the blank solution was also measured at $700 \mathrm{~nm}$ against the solvent used in solution preparation.

\section{Determination of brine shrimp lethality bioassay Brine shrimps}

Brine shrimp, Artemia salina Leach, are marine invertebrates also known as sea monkeys. They are about $1 \mathrm{~mm}$ in size. Freeze dried cysts were readily available at aquarium stores. The cysts lasted for several years and could be hatched without special equipment [16].

Brine shrimp lethality bioassay.

The lethal activity of the plant was evaluated using Brine shrimp lethality bioassay method [17]. Brine shrimps nauplii (Ocean 90, USA) were used as test organisms. Hatching was done by keeping the eggs in brine and supplying oxygen for $48 \mathrm{~h}$ at a stretch. The mature nauplii were then used in the experiment. DMSO was used as a solvent and also as a negative control. Vincristine sulfate was used as a reference standard in this case. After $24 \mathrm{~h}$ the test tubes were observed and the number of nauplii survived in each test tube was counted. From this, the percentage of mortality of brine shrimp nauplii was calculated for each concentration of the extract and then corrected using Abbott formula [18]. After correcting the \% mortality, probit analysis was performed and found out LC50 value calculated using Fenny probit analysis [19].

\section{Antimicrobial activity of plant extracts Microorganisms}

Three Gram-positive Bacillus subtilis (B. subtilis), Bacillus cereus (B. cereus), Staphylococcus aureus (S. aureus) and three Gram-negative Escherichia coli (E. coli), Salmonella typhi (S. typhi), and Salmonella abony (S. abony) bacteria 
were used for this investigation. As pure cultures, the bacterial strains were collected from the Institute of Nutrition and Food Science (INFS), University of Dhaka.

\section{Antimicrobial screening by disc diffusion technique}

Antimicrobial activity of the seed extracts was investigated by disc diffusion technique [20]. Subcultures prepared from pure cultures of seven microorganisms were used for the sensitivity test. Seed extract of $400 \mu \mathrm{g} / \mathrm{disc}$ concentrations was used for this investigation. Standard disc of Amoxicillin $(30 \mu \mathrm{g} / \mathrm{disc})$ was used as positive control. For negative control, blank discs that were impregnated with solvents followed by evaporation were used. Then $100 \mu \mathrm{L}$ of bacterial cell suspension was spread throughout the plates and then inverted and kept in an incubator at $37{ }^{\circ} \mathrm{C}$ for $24 \mathrm{~h}$. After that by measuring the diameter of the zones of inhibition (millimeter), the antimicrobial activities of the test samples were determined.

\section{Anthelmintic assay}

The Anthelmintic activity [21] was evaluated in adult earthworm (Pheretima posthuma). The groups of equalsized earthworms consisting of 3 earthworms in each group were released in $50 \mathrm{~mL}$ of sample with desired concentrations 10, 25 and $50 \mathrm{mg} / \mathrm{mL}$. One group of earthworms in 1\% Tween 80 was used as a control group and another group of earthworms in Piperazine citrate $(10 \mathrm{mg} / \mathrm{mL})$ used as a reference. Observations were made for the time taken for paralysis and death of individual worms. When earthworm does not make any movement except shaken vigorously considered as paralysis. When worms do not move if shaken vigorously or dipped in water at $50{ }^{\circ} \mathrm{C}$ were considered dead.

\section{Evaluation of peripheral analgesic activity Animals and experimental setup}

Swiss albino male mice of 25-30 g were collected from Pharmacology Laboratory, Department of Pharmacy, Jahangirnagar University, and were acclimatized to normal laboratory conditions for one week prior to the study and were assessed to a pellet diet and water ad libitum. The temperature of the facility was $25 \pm 3{ }^{\circ} \mathrm{C}$ and light/darkness alternated $12 \mathrm{~h}$ apart. The study was conducted following the approval by the Biosafety, Biosecurity and Ethical Committee [Approval Number: BBEC, JU/M 2018 (1)3] of Jahangirnagar University, Savar, Dhaka, Bangladesh.

\section{Acute toxicity study}

The acute oral toxicity test was performed following the guidelines of the Organization for Economic Cooperation and Development (OECD) for testing of chemicals, (Test Guideline 425) with some minor modifications (OECD 2008). Swiss albino male mice $(25-30 \mathrm{~g})(n=16)$ were divided into four groups with four animals each. Four different doses (500, 1000, 2000 and $3000 \mathrm{mg} / \mathrm{kg}$ ) of methanol extract of Mallotus repandus stem extracts were administered to each group via a stomach tube. Then, all the treated animals were observed for mortality and clinical signs of toxicity (i.e. general behaviour, respiratory pattern, cardiovascular signs, motor activities, reflexes and changes in skin and fur texture) following 1 , 2,3 and $4 \mathrm{~h}$ of post-administration on the first day but only once daily for the next three days following administration of the extract.

\section{Acetic acid induced writhing test}

According to Koster et al [22] method the experimental animals were randomly selected and divided into six groups consisting of five mice in each group. Group, I served as the control group and received 1\% Tween 80 in water. Group II received Diclofenac Na and Group III, IV was treated with the crude methanol extract, respectively. Whereas Group V, VI was treated with the crude petroleum ether extract. Forty-five minutes later each mouse was injected intra-peritoneally (i.p.) with $0.7 \%$ acetic acid at a dose of $10 \mathrm{~mL} / \mathrm{kg}$ body weight. After $15 \mathrm{~min}$ i.p. administration of acetic acid, the number of writhing responses for each animal was recorded for a subsequent 5 min period and the mean abdominal writhing for each group was obtained. The following formula was used to calculate the percentage inhibition of writhing:

\%Inhibition $=(1-$ No. of Writhing $($ Drug/Standard $)$ No. of Writhing $($ Control $)) \times 100$.

\section{Statistical analysis}

Values are presented as mean \pm SEM (Standard error of the mean) and mean \pm SD (Standard deviation). One way ANOVA followed by Dunnet, Bonferroni and LSD multiple comparisons was performed to analyze the data sets using SPSS version 16 (IBM software Inc., USA). $P<0.05$ was considered statistically significant. Besides Microsoft excel 2007 was also used to analyze different datasets.

\section{Results}

Phytochemical screening of $C$. renigera seed extracts

Both methanolic and petroleum ether extracts showed (Table 1) the presence of carbohydrates, flavonoids, saponins, and tannin. Besides alkaloids, glycosides and steroids were also contained in CRSM but absent in CRSP.

\section{Antioxidant activity evaluation}

Results of total phenol, total flavonoid content and total antioxidant capacity were presented in Table 2. Total phenol contents of CRSM and CRSP were found to be $85.59 \pm 0.66$ and $100.72 \pm 1.65 \mathrm{mg} / \mathrm{g}$, GAE respectively. Total flavonoid contents of methanol extract were $41.79 \pm$ $1.37 \mathrm{mg} / \mathrm{g}, \mathrm{QE}$ and petroleum ether extract was $19.85 \pm$ $0.51 \mathrm{mg} / \mathrm{g}$, QE. Total antioxidant capacity assay $7.53 \pm$ 
Table 1 Phytochemical constituents identified in the methanol and petroleum ether extracts of C. renigera seed extracts

\begin{tabular}{|c|c|c|c|c|}
\hline \multirow[t]{2}{*}{ Phytochemicals } & \multirow[t]{2}{*}{ Name of the test } & \multirow[t]{2}{*}{ Observed changes } & \multicolumn{2}{|l|}{ Result } \\
\hline & & & CRSM & CRSP \\
\hline \multirow[t]{4}{*}{ Alkaloids } & Mayer's test & Creamy white precipitate & + & - \\
\hline & Hager's test & Yellow crystalline precipitate & ++ & + \\
\hline & Wagner's test & Brown or deep brown precipitate & + & - \\
\hline & Dragendorff's test & Orange or orange-red precipitate & + & - \\
\hline \multirow[t]{4}{*}{ Carbohydrates } & Molisch's test (General test for Carbohydrates) & $\begin{array}{l}\text { A red or reddish violet ring is formed at the junction } \\
\text { of two layers and on shaking a dark purple solution is formed }\end{array}$ & ++ & $+/-$ \\
\hline & Barfoed's test (General test for Monosaccharides) & Red precipitate & - & - \\
\hline & Fehling's test(for reducing sugar) & A red or brick-red precipitate & + & + \\
\hline & Test for combined Reducing Sugar & A brick-red precipitate & + & $+/-$ \\
\hline \multirow[t]{2}{*}{ Glycosides } & General test & Yellow color & + & - \\
\hline & Test for Glucoside & $\begin{array}{l}\text { Production of brick-red precipitation (carried out with the } \\
\text { hydrolyzed extract) }\end{array}$ & + & - \\
\hline Flavonoids & General test & Red color & + & + \\
\hline Saponins & Frothing test & Formation of stable foam & + & + \\
\hline Steroids & Libermann-Burchard's test & Greenish color & + & - \\
\hline Tannins & Lead acetate test & A yellow or red precipitate & + & + \\
\hline
\end{tabular}

$[++=$ Strong presence, $+=$ Presence, $-=$ Absence,$+/-=$ Presence/Absence not confirmed $]$; CRSM = Cassia renigera seed methanol extract, CRSP $=$ Cassia renigera seed petroleum ether extract

0.45 and $184.93 \pm 1.82 \mathrm{mg} / \mathrm{g}$, AAE were the result of CRSM and CRSP, respectively. The extracts (CRSM and CRSP) differed significantly $(P<0.05)$ in total phenol, total flavonoid and total antioxidant capacity assays.

In DPPH assay between two extracts, CRSM was found to show good $\mathrm{IC}_{50}$ value $99.83 \pm 0.23 \mu \mathrm{g} / \mathrm{mL}$, and CRSP showed moderate activity $148.49 \pm 1.26 \mu \mathrm{g} / \mathrm{mL}$ whereas ascorbic was found to exhibit a very good $\mathrm{IC}_{50}$ value of $17.47 \pm 0.08 \mu \mathrm{g} / \mathrm{mL}$. In NO radical scavenging method, CRSM show moderate activity $\left(\mathrm{IC}_{50}\right.$ value $113.51 \pm 3.00 \mu \mathrm{g} / \mathrm{mL})$ incomparable to $\mathrm{AA}\left(\mathrm{IC}_{50}\right.$ value $23.41 \pm 0.47 \mu \mathrm{g} / \mathrm{mL}$ ). In both $\mathrm{DPPH}$ and $\mathrm{NO}$ radical scavenging capacity assay CRSM, CRSP and AA differed significantly $(P<0.05)$ (Table 3$)$.

In the CUPRAC method, CRSM exhibited concentrationdependent activity compared to AA (Fig. 1(a)). CRSP shows very poorly reducing power capacity but CRSM shows good concentration-dependent activity (Fig. 1(b)).

\section{Brine shrimp lethality bioassay}

In Brine shrimp lethality bioassay, methanolic ether extract was found to be the most toxic to brine shrimp nauplii, with $\mathrm{LC}_{50}$ of $74.44 \mu \mathrm{g} / \mathrm{mL}(\mathrm{X} 2=139.86, P<0.05)$ whereas petroleum ether extract showed $\mathrm{LC}_{50}$ value $121.49 \mu \mathrm{g} / \mathrm{ml}$ $\left(\chi^{2}=183.86, P<0.05\right)$. The standard anticancer drug Vincristine sulphate (VS) has exhibited $\mathrm{LC}_{50}$ value $1.50 \mu \mathrm{g} / \mathrm{ml}\left(\chi^{2}=151.61, P<0.05\right)$. Dataset is presented in Table 4.

\section{Antimicrobial activity}

In the overall antimicrobial study (Table 5), CRSM showed better activity than CRSP. The highest activity (zone of inhibition $11.75 \pm 0.35 \mathrm{~mm}$ ) was exhibited by methanol extract against $S$. typhi. Lowest activity (zone of inhibition $0.00 \pm 0.00 \mathrm{~mm}$ ) was observed against $B$. cereus by both extracts. Besides, CRSP also showed $0.00 \pm$ $0.00 \mathrm{~mm}$ of the zone of inhibition against S. abony.

\section{Anthelmintic activity}

Earthworm used in anthelmintic activity determination of the plant extracts. CRSM showed better activity than CRSP. Anthelmintic activity increased with the concentration of the test samples. CRSM of $50 \mathrm{mg} / \mathrm{mL}$ showed

Table 2 Total phenol, total flavonoid and total antioxidant capacity of different extracts of C. renigera seed

\begin{tabular}{llll}
\hline Extracts & $\begin{array}{l}\text { Total phenol } \\
(\mathrm{mg} / \mathrm{g}, \mathrm{GAE})\end{array}$ & Total flavonoid (mg/g, QE) & Total antioxidant capacity (mg/g, AAE) \\
\hline CRSM & $85.59 \pm 0.66^{\mathrm{b}}$ & $41.79 \pm 1.37^{\mathrm{a}}$ & $7.53 \pm 0.45^{\mathrm{b}}$ \\
CRSP & $100.72 \pm 1.65^{\mathrm{a}}$ & $19.85 \pm 0.51^{\mathrm{b}}$ & $184.93 \pm 1.82^{\mathrm{a}}$
\end{tabular}

Values are the mean of duplicate experiments and represented as mean $\pm \mathrm{SD}(n=2)$. Values in same column with different superscripts are significantly different $(P<0.05)$. Student's t-test was performed to analyze this data set. GAE Gallic Acid Equivalent, QE Quercetin Equivalent, $A A E$ Ascorbic Acid Equivalent 
Table 3 DPPH and NO radical scavenging assay of extracts of $C$. renigera seed

\begin{tabular}{lll}
\hline Extracts/Standard & DPPH $\left(I C_{50}(\mu \mathrm{g} / \mathrm{mL})\right)$ & $\mathrm{NO}\left(I C_{50}(\mu \mathrm{g} / \mathrm{mL})\right)$ \\
\hline CRSM & $99.83 \pm 0.23^{\mathrm{b}}$ & $113.51 \pm 3.00^{\mathrm{b}}$ \\
CRSP & $148.49 \pm 1.26^{\mathrm{a}}$ & $369.79 \pm 0.15^{\mathrm{a}}$ \\
AA & $17.47 \pm 0.08^{\mathrm{c}}$ & $23.41 \pm 0.47^{\mathrm{c}}$
\end{tabular}

Values are the mean of duplicate experiments and represented as mean \pm SD $(n=2)$. Values in same column with different superscripts are significantly different $(P<0.05)$. One way ANOVA followed by Bonferroni multiple comparisons was performed to analyze data sets

maximum anthelmintic activity which is comparable to the standard (Piperazine Citrate, $10 \mathrm{mg} / \mathrm{mL}$ ) (Table 6).

\section{Acetic acid induced writhing test}

Both $500 \mathrm{mg} / \mathrm{kg}$ and $1000 \mathrm{mg} / \mathrm{kg}$ body weight doses, the CRSM produced significant $39.64 \%$ and $58.73 \%$ writhing inhibition $(P<0.05)$ in test animals, respectively. In the case CRSP, only $1000 \mathrm{mg} / \mathrm{kg}$ body weight dose showed a significant effect $(P<0.05)$. The reduction of a number of writhing by extracts was in a dose dependent manner. The standard Diclofenac Na showed 73.02\% inhibition of writhing (Table 7).

\section{Discussion}

Phytochemicals are known as biologically active compounds and responsible for antioxidant, antimicrobial, anticancer and antifungal activities [23]. The presence of some of the secondary metabolite chemicals in CRSM and CRSP (Table 1) gives a hint that the plant might be of medicinal importance. Phenolics compounds are well known as an antioxidant which scavenges free radicals associated with oxidative damage. Flavonoids modulating lipid peroxidation involved in atherogenesis, thrombosis, and carcinogenesis. Polyphenols proclaimed several biological effects such as conservancy of LDL oxidation in vivo with significant consequences in atherosclerosis and also save DNA from oxidative damage with important consequences in the age-related development of some cancers [24]. It has been proved that flavonoids pharmacological effects are correlating with their antioxidant potentialities [25]. Results gained in this study revealed that the level of total phenolic and total flavonoid content in the CRSM and CRSP were considerably significant (Table 2). This may give credence for the antioxidant claim.

$\mathrm{DPPH}$ free radical scavenging activity assay is the widely used procedure to assess the antioxidant activity of natural plant extracts. The degree of discoloration implies the extract's scavenging potential, which is due to the ability of hydrogen donation [26]. Nitric oxide is a potent pleiotropic inhibitor of physiological processes and overproduction of nitric oxide manifest in various pathological conditions such as relaxation of smooth muscle, neuronal signaling, and regulation of cell-mediated cytotoxicity and inactivation of platelet aggregation [27]. Nitric oxide plays many roles as an effector molecule in several biological systems involving neuronal messenger, vasodilator [28]. In the quantitative assay, CRSM has shown better activity than CRSP in both case of DPPH free radical and NO scavenging capacity assay and is significant compared to the standard (ascorbic acid) (Table 3). Reducing power is related with antioxidant activity and may serve as a reflection role of the antioxidant activity compounds which possess reducing power play electron donors and can abate the oxidized intermediates of lipid peroxidation processes so that they can act as primary and secondary antioxidants [29]. The reducing capacity assessment reveals that both CRSM and CRSP have the potential reducing capacity (Fig. 1).

As plants are a significant source of drug and many plants have been screened whether they reflect therapeutically active compounds. So, it is emergent to evaluate the antimicrobial activity of $C$. renigera [30]. For the antimicrobial assay, disc diffusion method was used. In this
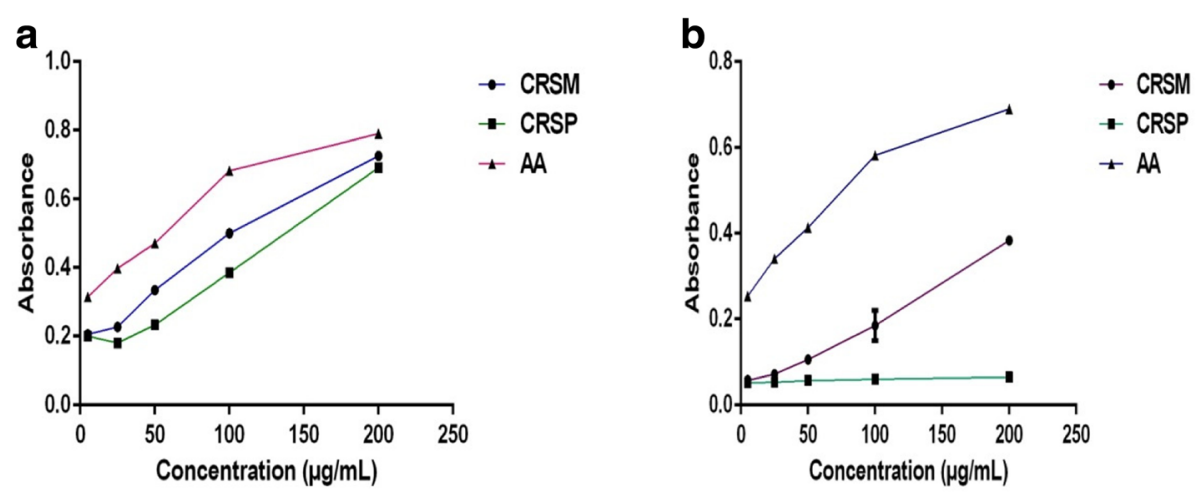

Fig. 1 a Cuprac reducing capacity assessment of CRSM, CRSP and standard. Values are presented as mean \pm standard deviation $(n=2)(\mathbf{b})$ Reducing power capacity assessment of two different seed extracts and standard. Values are presented as mean \pm SD $(n=2)$ 
Table 4 Brine shrimp lethality of different extracts of C. renigera seed

\begin{tabular}{lllll}
\hline Test Sample & $\mathrm{LC}_{50}(\mu \mathrm{g} / \mathrm{mL})$ & $\mathrm{Cl}$ & $X^{2}$ & $P$ value \\
\hline CRSM & $74.44^{\mathrm{b}}$ & $54.83-105.05$ & 139.84 & $<0.05$ \\
CRSP & $121.49^{\mathrm{a}}$ & $89.39-175.20$ & 183.86 & $<0.05$ \\
VS & $1.50^{\mathrm{c}}$ & $1.10-2.13$ & 151.61 & $<0.05$ \\
\hline
\end{tabular}

Cl Confidence Interval, $X 2$ Chi-square, VS Vincristine sulphate. The experiments were done in triplicate $(n=3)$. Fenny probit analysis was performed to find out $\mathrm{LC}_{50}$ values, confidence interval limit, chi-square and $P$ value. Values in the same column with different superscripts are significantly different $(P<0.05)$. One way ANOVA followed by Bonferroni multiple comparisons was performed to analyze data sets

assay, CRSM and CRSP showed moderate inhibitory property against various pathogenic microbial species except for B. cereus when compared to standard drug Amoxicillin. The extracts showed more potent antimicrobial activity against Gram-negative bacteria than Gram-positive. The most remarkable activity (zone of inhibition $11.75 \pm 0.35 \mathrm{~mm}$ ) was shown by CRSM against S. typhi whereas the zone of inhibition showed by the standard drug was $22.50 \pm 0.71 \mathrm{~mm}$. Preliminary phytochemical screening of $C$. renigera showed the appearance of a number of bioactive constituents such as alkaloids, glycosides, flavonoids, saponin, steroids, carbohydrates and tannins which are attributed for this property [31]. This polyphenolic compounds caused inhibition of a wide range of microorganism which is reported by some preceding studies [32]. Phenol functions as a chemical antiseptic [33]. Tannins and flavonoids have been exhibited important antibacterial activity $[34,35]$. The antimicrobial activities of flavonoids have been exerted because of their capability to form complex with extracellular and soluble protein and to complex with bacterial cell wall [36] while tannins have astringent property that can induce complexation with microbial enzymes or substrates, iron deprivation, toxic action on microbial membranes, complexation of metal ions [37]. Plant alkaloids [38], saponins [39] and steroids [40] are also responsible for the antimicrobial

Table 5 Antimicrobial activity of methanol and petroleum ether extracts of $C$. renigera seed in disc diffusion method

\begin{tabular}{llll}
\hline Organisms & \multicolumn{2}{l}{ Zone of Inhibition $(\mathrm{mm})$} \\
\cline { 2 - 4 } & CRSM & CRSP & AMOXICILLIN \\
\hline B. subtilis & $7.25 \pm 0.35^{\mathrm{b}}$ & $7.50 \pm 0.71^{\mathrm{b}}$ & $13.00 \pm 1.41^{\mathrm{a}}$ \\
B. cereus & $0.00 \pm 0.00^{\mathrm{b}}$ & $0.00 \pm 0.00^{\mathrm{b}}$ & $16.25 \pm 0.35^{\mathrm{a}}$ \\
S. aureus & $7.75 \pm 0.35^{\mathrm{b}}$ & $6.25 \pm 0.35^{\mathrm{b}}$ & $20.00 \pm 1.41^{\mathrm{a}}$ \\
E. coli & $10.00 \pm 0.00^{\mathrm{c}}$ & $8.5 \pm 0.71^{\mathrm{b}}$ & $28.75 \pm 0.35^{\mathrm{a}}$ \\
S. typhi & $11.75 \pm 0.35^{\mathrm{b}}$ & $8.00 \pm 0.00^{\mathrm{c}}$ & $22.50 \pm 0.71^{\mathrm{a}}$ \\
S. abony & $7.25 \pm 0.35^{\mathrm{b}}$ & $0.00 \pm 0.00^{\mathrm{c}}$ & $28.75 \pm 1.77^{\mathrm{a}}$ \\
\hline
\end{tabular}

Values are presented as mean $\pm \mathrm{SD}(n=2)$. Values with different superscript in each row are significantly different from one another $(P<0.05)$. One way ANOVA followed by LSD multiple comparisons were performed to analyze this data set
Table 6 Anthelmintic activity of standard drug and sample

\begin{tabular}{llll}
\hline Treatment & Concentration & $\begin{array}{l}\text { Paralysis time } \\
\text { (minutes) }\end{array}$ & $\begin{array}{l}\text { Death time } \\
\text { (minutes) }\end{array}$ \\
\hline Control & 10 & No paralysis & No death observed \\
Piperazine Citrate & 10 & $20.67 \pm 0.67$ & $37.67 \pm 0.88$ \\
CRSM & 10 & $>90$ & $>90$ \\
& 25 & $28.00 \pm 1.53$ & $53.00 \pm 1.53$ \\
& 50 & $17.33 \pm 0.67$ & $42.67 \pm 0.88$ \\
CRSP & 10 & $>90$ & $>90$ \\
& 25 & $>90$ & $>90$ \\
& 50 & $32.67 \pm 1.86$ & $80.00 \pm 2.65$
\end{tabular}

Values are presented as mean \pm SEM $(n=3)$

activity. However, further research on this plant is crucial for identification and isolation of the responsible compounds for discovery of each of their specific mechanism of action.

Brine shrimp lethality is a general, safe, practical and economic bioassay which is indicative of cytotoxicity and various other pharmacologic actions [17]. The National Cancer Institute (NCI, USA) showed interrelation between in vitro growth inhibition of human solid tumor cell and the brine shrimp assay that is significant because this bioassay examined as a prescreening tool for anti-tumor and anti-cancer drug research [41]. Using brine shrimp bioassay accordant to Meyer et al [17] extracts derived from natural resources which have LC50 $\geq 1000 \mathrm{~g} / \mathrm{mL}$ were claimed to contain bioactive principles. Limit of brine shrimp toxicity for plant extract which was established as LC50 values above $1000 \mu \mathrm{g} / \mathrm{mL}$ are non-toxic, between 500 and $1000 \mu \mathrm{g} / \mathrm{mL}$ are weak toxic, and below $500 \mu \mathrm{g} / \mathrm{mL}$ are toxic [42]. In this study methanol and petroleum ether extract showed the good LC50 value of 74.44 and $121.49 \mu \mathrm{g} / \mathrm{mL}$, respectively. Therefore both extracts are considered as bioactive and toxic against brine shrimp nauplii. The presence of different secondary metabolites like alkaloid, glycoside, steroids, tannin, and flavonoid (Table 1) in the extracts may play a key role to show the cytotoxic effect [43]. Besides, further toxicity studies could be conducted on individual cell line to confirm the bioactivity of phytochemical groups.

Earthworm was used for the anthelmintic activity test because it has much anatomical and physiological similarity with the human intestinal roundworm parasite [21]. Ayers et al 2007 revealed that alkaloids in the aerial parts of Cissampelos capensis (Menispermaceae) and Macleaya microcarpa (Maxim.) Fedde (Papaveraceae) are known to be liable for their anthelminthic activity [44]. Tannins exert anthelmintic activity by binding to glycoprotein on the cuticle of the parasite. They hinder energy production in helminths parasites by uncoupling oxidative phosphorylation $[45,46]$. 
Table 7 Effects of C. renigera seed methanol and petroleum ether extracts in acetic acid induced writhing test

\begin{tabular}{llll}
\hline & Dose $(\mathrm{mg} / \mathrm{Kg})$ & Number of writhing responses & \% Inhibition \\
\hline Control & $1 \%$ Tween 80 in water $(10 \mathrm{~mL} / \mathrm{Kg})$ & $12.60 \pm 0.51$ & - \\
Diclofenac Na (Standard) & 100 & $3.40 \pm 0.24^{*} \mathrm{~d}$ & 73.02 \\
CRSM & 500 & $7.60 \pm 0.49^{*}$ a,b & 39.64 \\
& 1000 & $5.20 \pm 0.49^{*} \mathrm{c}, \mathrm{d}$ & 58.73 \\
CRSP & 500 & $9.80 \pm 1.46^{a}$ & 22.22 \\
& 1000 & $6.80 \pm 0.66^{*}{ }^{\mathrm{b}, \mathrm{c}}$ & 46.03 \\
\hline
\end{tabular}

Values are presented as mean \pm SEM $(n=5)$. One way ANOVA followed by Dunnett's multiple comparisons was performed to analyze this data set; $P<0.05$ was considered statistically significant when compared against a control. One way ANOVA followed by LSD multiple comparisons was performed among the standard and the plant extracts. In this case values with different superscript in the same column are significantly different from one another $(P<0.05)$

For the evaluation of the potentiality of peripherally acting analgesics, the acetic acid-induced writhing response is a widely used sensitive procedure. Acetic acid induced writhing model may cause the localized inflammatory condition and induce pain sensation. Free arachidonic acid is released from tissue phospholipid in the response of such pain stimulation [47]. The writhing response is considered to be caused by peritoneal mast cells [48], acid-sensing ion channels and the prostaglandin pathways [49]. The flavonoid, a powerful antioxidant, shows analgesic activity $[50,51]$. Flavonoids primarily show analgesic activity by targeting prostaglandins [52]. There are also reports on the role of tannins in antinociceptive activity [53] steroids [54] and saponins [55] also possess pain-relieving activity. CRSM and CRSP both showed dose-dependent antinociceptive activity. The highest activity (58.73\% inhibition of writhing) was exhibited by CRSM at $1000 \mathrm{mg} / \mathrm{Kg}$ dose which is comparable to the standard (73.02\% inhibition of writhing) at $100 \mathrm{mg} / \mathrm{Kg}$ dose. In phytochemical screening test suggested that different phytochemical compounds were present in both extracts of $C$. renigera seed (Table 1). Maybe the presence of these secondary bioactive compounds played an important role to exhibit antinociceptive activity by inhibiting pathways of prostaglandin synthesis or by other mechanisms. Further studies are required to ascertain the exact mechanism of the antinociceptive action of these bioactive compounds.

\section{Conclusion}

To conclude it can be said that the extracts of Cassia renigera seed possess significant bioactivities including antimicrobial, anthelmintic and analgesic activities. Different established in vitro and in vivo pharmacological tests were performed to assess the efficacy of the extracts, providing a scientific basis for its traditional uses for treating various ailments. There is every possibility to suggest that these activities may be due to the presence of different secondary metabolite compounds. Further well-designed more research activities are required to isolate the bioactive molecules and to elucidate their possible molecular mechanisms of actions.

\section{Abbreviations}

AAE: Ascorbic acid equivalent; $B$. cereus: Bacillus cereus; $B$. subtilis: Bacillus subtilis; $C$. renigera: Cassia renigera; CRSM: Cassia renigera seed methanol extract; CRSP: Cassia renigera seed petroleum ether extract; DPPH: 1,1- diphenyl-2-picrylhydrazyl; E. coll: Escherichia coli; GAE: Gallic acid equivalent; i.p: intra-peritonially; LC50: Lethal concentration 50; QE: Quercetin equivalent; S. abony: Salmonella abony; S. aureus: Staphylococcus aureus; S. typhi: Salmonella typhi

\section{Acknowledgments}

The authors would like to express their thanks to the Department of Pharmacy, Jahangirnagar University for providing necessary support to perform this study.

\section{Funding}

No funding was received.

\section{Availability of data and materials}

Not applicable.

\section{Authors' contributions}

This work was carried out in collaboration between all authors. Author MMH conceived of the presented research project. Author MMH, MM, and MRUM performed the experimental work. Authors $\mathrm{MMH}, \mathrm{NU}, \mathrm{AD}, \mathrm{MSH}$, and MMK managed the literature searches as well as performed the statistical analysis. Author MMH and MM wrote the first draft of the manuscript which was corrected by TBW and MFI. The overall research project was supervised by MMHC. Authors TBW, MFI, and MMHC finalized the final drafting of the manuscript. All authors read and approved the final manuscript.

Ethics approval and consent to participate

The study was conducted following the approval by the Biosafety, Biosecurity and Ethical Committee [Approval Number: BBEC, JU/M 2018 (1)3] of Jahangirnagar University, Savar, Dhaka, Bangladesh.

Consent for publication Not applicable.

Competing interests

The authors declare that they have no competing interests.

\section{Publisher's Note}

Springer Nature remains neutral with regard to jurisdictional claims in published maps and institutional affiliations.

\section{Author details}

'Department of Pharmacy, Mawlana Bhashani Science and Technology University, Santosh, Tangail 1902, Bangladesh. ²Department of Pharmacy, Jahangirnagar University, Savar, Dhaka 1342, Bangladesh. ${ }^{3}$ Department of Pharmacy, Noakhali Science and Technology University, Noakhali 3814, Bangladesh. ${ }^{4}$ College of Health and Pharmaceutical Sciences, School of Pharmacy, University of Louisiana at Monroe, Monroe, LA, USA. 
Received: 23 April 2018 Accepted: 1 November 2018

Published online: 03 December 2018

\section{References}

1. Khan M, Kibara M, Oinoloso B. Antibacterial activity of the alkaloidal constituents of the root bark of Eupomatia lourina. Pharm Biol. 2003:41:277-80.

2. Raghuveer C, Tandon RV. Consumption of functional food and our health concerns. Pak J Physiol. 2009;5(1):76-83.

3. Rios JL, Recio MC. Medicinal plants and antimicrobial activity. J Ethnopharmacol. 2005;100:80-4.

4. Hossain E, Chandra G, Nandy AP, Mandal SC, Gupta JK. Anthelmintic effect of a methanol extract of leaves of Dregea volubilis on Paramphistomum explanatum. Parasitol Res. 2012;110:809-14.

5. Yung-Jia Chiu, Tai-Hung Huang, Chuan-Sung Chiu, Tsung-Chun Lu, Ya-Wen Chen,Wen-Huang Peng, et al. Analgesic and Antiinflammatory activities of the aqueous extract from Plectranthus amboinicus (Lour.) Spreng. Both In Vitro and In Vivo. Hindawi publishing corporation Evidence-Based Complementary and Alternative Medicine 2012, Article ID 508137, 11 pages https://doi.org/10.1155/2012/50813

6. Yen GC, Chung DY. Antioxidant effects of extracts from Cassia tora L. prepared under different degrees of roasting on the oxidative damage to biomolecules. J Agric Food Chem. 1999:47:1326-32.

7. Hossain MM, Mondal M, Hossain MP, Uddin MS, Uddin N, Hasan MM, Hossain MS, Islam AFMM, Rana MS. In vitro antioxidant, brine shrimp lethality and antimicrobial activities of methanol and petroleum ether extracts of Cassia renigera fruit. J Food Measurement Characterization. 2015; 9(1):68-75. https://doi.org/10.1007/s11694-014-9211.

8. Ghani A. Medicinal Plants of Bangladesh. 2nd ed. Dhaka: The Asiatic society of Bangladesh; 2003.

9. Velioglu YS, Mazza G, Gao L, Oomah BD. Antioxidant activity and total phenolics in selected fruits, vegetables, and grain products. J Agric Food Chem. 1998:46:4113-7.

10. Wang SY, Jiao H. Correlation of antioxidant capacities to oxygen radical scavenging enzyme activities in blackberry. J Agric Food Chem. 2000;48: 5672-6.

11. Prieto P, Pineda M, Aguilar M. Spectrophotometric quantitation of antioxidant capacity through the formation of a phosphomolybdenum complex: specific application to the determination of vitamin E. Anal Biochem. 1999;269:337-41.

12. Braca A, Tommasi ND, Bari LD, Pizza C, Politi M. Antioxidant principles from Bauhinia terapotensis. J Nat Prod. 2001;64:892-5.

13. Govindarajan R, Rastogi S, Vijayakumar M, Shirwaikar A, Rawat AKS, Mehrotra $\mathrm{S}$, et al. Studies on the antioxidant activities of Desmodium gangeticum. Biol Pharm Bull. 2003:26:1424-142.

14. Resat A, Kubilay G, Mustafa O, Saliha EK. Novel total antioxidant capacity index of dietary polyphenols and vitamin $C$ and $E$, using their cupric ion reducing capability in the presence of neocuproine: CUPRAC method. J Agric Food Chem. 2004;52:7970-81.

15. Oyaizu M. Studies on products on Browning reaction - Antioxidative activities of products of Browning reaction prepared from glucosamine. Japanese J Nutr. 1986;44:307-15.

16. Lieberman MA. Brine shrimp bioassay for measuring toxicity and remediation of chemicals. J Chem Ed. 1999;76:1689-91.

17. Meyer BN, Ferrigni NR, Putnam JE, Jacobsen LB. Brine shrimp: a convenient general bioassay for active plant constituents. Planta Med. 1982;45:31-4

18. Abbott WS. A method of computing the effectiveness of an insecticide. J Econ Ent. 1925:18:265-7.

19. Fenney DJ. Probit analysis. Cambridge: Cambridge University Press; 1982.

20. Bauer AW, Kirby WM, Sherris JC, Turck M. Antibiotic susceptibility testing by a standardized single disk method. Am J Clin Pathol. 1966;45(4):493-6.

21. Ajaiyeoba EO, Onocha PA, Olarenwaju OT. In-vitro anthelmintic properties of Buchholzia coiaceae and Gynandropsis gynandra extract. Pharm Biol. 2001 39(3):217-20.

22. Koster $\mathrm{R}$, Anderson M, De-Beer EJ. Acetic acid analgesic screening. Fed Proc 1959:18:412-7.

23. Hossain MA, Nagooru MR. Biochemical profiling and total flavonoids contents of leaves crude extract of endemic medicinal plant Corydyline terminalis L. Kunth. Pharmacogn J. 2011:3(24):25-30.

24. Nidyaletchmy SR, Suerialoasan N, Saravana KS, Norhanom AW, Kae SS. Phenolic content, antioxidant effect and cytotoxic activity of Leea indica leaves. BMC Comp Alter Med. 2012;12:128-34.
25. Shi J, Yu J, Pohorly J, Young C, Bryan M. Wu Y. optimization of the extraction of polyphenols from grapes seed meal by aqueous ethano solution. Food Agric Environ. 2006;1:42-7.

26. Barreira JCM, Ferreira ICFR, Oliveira MBPP, Pereira JA. Antioxidant activities of the extracts from chestnut flower, leaf, skins and seed. Food Chem. 2008; 107:1106-13.

27. Kumaran A, Joel R. Antioxidant and free radical scavenging activity of an aqueous extract of Coleus aromaticus. Food Chem. 2006;97:109-14

28. Hagerman AE, Riedl KM, Jones GA, Sovik KN, Ritchard NT, Hartzfeld PW. High molecular weight plant polyphenolics (tannins) as biological antioxidants. J Agric and Food Chem. 1998;46:1887-92.

29. Miller HE, Rigelhof F, Marquart L, Prakash A, Kanter M. Antioxidant content of whole grain breakfast cereals, seeds and vegetables. J Am Coll Nutr. 2000;19(3):312S-9S.

30. Rosy BA, Joseph H. Rosalie. Phytochemical, pharmacognostical, antimicrobial activity of Indigofera spalathoids Vahl., (Fabaceae). Int J Biol Technol. 2010;1: $12-5$.

31. Zuraini Z, Yoga Latha L, Suryani S, Sasidharan S. Anticandida albicans activity of crude extract of the local plant, winged beans leaf. Plant Kuala Lumpur. 2007;80:653-7.

32. Konaté K, Yomalan K, Sytar O, Brestic M. Antidiarrheal and antimicrobial profiles extracts of the leaves from Trichilia emetica Vahl. (Meliaceae). Asian Pac J Trop Biomed. 2015;5(3):242-8.

33. Bazrafshan E, Mostafapour FK, Mansourian HJ. Phenolic compounds: health effects and its removal from aqueous environments by low cost adsorbents. Health Scope. 2013;2(2):65-6.

34. Rabe T, Mullholland D, van Staden J. Isolation and identification of antibacterial compounds from Vernonia colorataleaves. J Ethnopharmacol. 2002;80:91-4

35. Medini F, Fellah H, Ksouri R, Abdelly C. Total phenolic, flavonoid and tannin contents and antioxidant and antimicrobial activities of organic extracts of shoots of the plant Limonium delicatulum. J Taibah Univ Sc. 2014;8(3):216-24.

36. Cowan MM. Plants products as antimicrobial agents. Clin Microbiol Rev. 1999:12:564-82

37. Akiyama H, Fujii K, Yamasaki O, Oono T, Iwatsuki T. Antibacterial action of several tannins against Staphylococcus aureus. J Antimicrob Chemother. 2001:48:487-91.

38. Tanaka JCA, Silva CC, Oliveira ALB, Nakamura CV, Dias Filho BP. Antibacterial activity of indole alkaloids from Aspidosperma ramiflorum. Braz J Med Biol Res. 2006;39(3):387-91.

39. Avato P, Bucci R, Tava A, Vitali C, Rosato A, Bialy Z. Antimicrobial activity of saponins from Medicagosp.: structure-activity relationship. Phytother Res. 2006;20(6):454-7.

40. Taleb-Contini SH, Salvador MJ, Watanabe E, Ito IY, Oliveira DCR. Antimicrobial activity of flavonoids and steroids isolated from two Chromolaena species. Braz J Pharma Sci. 2003;39(4):403-8.

41. Anderson JE, Goetz CM, McLaughlin JL, Suffness M. A blind comparison of simple bench-top bioassay and human tumour cell cytotoxicities as antitum or prescreens. Phytochem Anas. 1991:2:107-11.

42. Déciga-Campos M, Rivero-Cruz I, Arriaga-Alba M, Castañeda-Corral G, Angeles-López GE, Navarrete A. Acute toxicity and mutagenic activity of Mexican plants used in traditional medicine. J Ethnopharmacol. 2007;110: 334-42.

43. Ozçelik B, Kartal M, Orhan I. Cytotoxicity, antiviral and antimicrobial activities of alkaloids, flavonoids, and phenolic acids. Pharm Biol. 2011:49(4):396-402.

44. Ayers S, Zink DL, Mohn K, Powell JS, Brown CM, Murphy T, et al. Anthelmintic activity of aporphine alkaloids from Cissampelos capensis. Planta Med. 2007:3(3):296-9.

45. Thompson DP, Geary TG. The structure and function of helminth surfaces. In: Biochemistry and molecular biology of parasites. New York: Academic Press; 1995. p. 203-32.

46. Martin RJ. Mode of action of anthelmintic drugs. Vet J. 1997:154:11-34.

47. Ahmed F, Hossain MH, Rahman AA, Shahid IZ. Antinociceptive and sedative effects of the bark of Cerbera odollam Gaertn. Ori Pharm Exp Med. 2006:6:344-8.

48. Ronaldo AR, Mariana LV, Sara MT, Adriana BPP, Steve P, Ferreira SH, et al. Involvement of resident macrophages and mast cells in the writhing nociceptive response induced byzymosan and acetic acid in mice. Eur J Pharmacol. 2000:387:111-8.

49. Hossain MM, Ali MS, Saha A, Alimuzzaman M. Antinociceptive activity of whole plant extracts of Paederia foetida. Dhaka University J Pharm Sci. 2006; 5:67-9. 
50. Xin HL, Zhai XF, Zheng X, Zhang L, Wang YL, Wang Z. Anti-inflammatory and analgesic activity of total flavone of Cunninghamia lanceolata. Molecules. 2012;17(8):8842-50.

51. Sannigrahi S, Mazumder UK, Pal D, Mishra ML, Maity S. Flavonoids of Enhydra Fluctuans exhibits analgesic and anti-inflammatory activity in different animal models. Pak J Pharm Sci. 2011;24(3):369-75.

52. Rao MR, Rao YM, Rao AV, Prabhkar MC, Rao CS, Muralidhar N. Antinociceptive and anti-inflammatory activity of a flavonoid isolated from Caralluma attenuate. J Ethnopharmacol. 1998;62:63-6.

53. Vanu MR, Palanivelu S, Panchanatham S. Immunomodulatory and anti-inflammatory effects of Semecarpus anacardium Linn. Nut milk extract in experimental inflammatory conditions. Biol Pharm Bull. 2006;29:693-700

54. Afzal M, Gupta G, Kazmi I, Rahman M, Afzal O, Alam J, et al. Anti-inflammatory and analgesic potential of a novel steroidal derivative from Bryophyllum pinnatum. Fitoterapia. 2012:83(5):853-8.

55. Akkol EK, Tatli II, Akdemir ZS. Antinociceptive and anti-inflammatory effects of saponin and iridoid glycosides from Verbascum pterocalycinum var. mutense hub.-Mor. Z Naturforsch C. 2007;62(11-12):813-20.

\section{Submit your manuscript to a SpringerOpen ${ }^{\circ}$ journal and benefit from:}

- Convenient online submission

- Rigorous peer review

- Open access: articles freely available online

- High visibility within the field

- Retaining the copyright to your article

Submit your next manuscript at $\boldsymbol{\nabla}$ springeropen.com 